\title{
CONTRA EL SILENCIO POR LA DESOBEDIENCIA
}

POR

ANGELICA GORODISCHER

Como siempre, el lote que nos toca a las mujeres es doble, como la jornada de trabajo, como la culpa, como la responsabilidad. Creo que no hay país en Latinoamérica que no haya implantado alguna vez la censura. Que no hay país en el que esa censura exógena no se haya sumado, en las escritoras, a la otra, no exógena, no endógena, no congénita: a la que es cxpresión de la eficacia de una ley que hemos internalizado profunda y profusamente.

"Hay algo siniestro en toda ley, $y$ es que sus mandatos no tienen nada que ver con la vida» (D. H. Lawrence). La censura, el censere como ley de evaluación, y su consecuencia la prohibición, el pro-habere, el tener, pero lejos, tampoco tienen nada que ver con la vida. Manejada por un poder que produce el mismo miedo que consume, es un arma perfecta, eficiente, de efecto largamente residual y absolutamente deletéreo. Apunta a suprimir la movilidad, la variedad, la multiplicidad de la palabra, es decir, tira a matar.

La censura emanada del poder totalitario se ejerce prohibiendo textos. Prohibir un libro es petrificar la palabra, y petrificarlo es anularla. Que ese poder prohíba libros es coherente, es lógico. Puede ser un escándalo, pero no es un escándalo inesperado.

En estos casos, a la palabra hablada se la reglamenta, y a partir del reglamento se la vigila. Tal vez prohibirla sea imposible, pero es que además no tiene objeto: el lenguaje hablado termina por reproducir las formas del poder, se contagia, se contamina, y un día, casi sin darnos cuenta, hemos pasado de la expresión de la alternativa al comunicado castrense.

El lenguaje escrito, en cambio, la palabra del escritor, debe prohibirse, petrificarse hasta la muerte. Porque la escritura «revela el mundo escon- 
dido», es contestataria, es subversiva, es intencional. «El escritor no se encierra en una torre de marfil, sino en un depósito de dinamita», dice Max Frisch (1979).

Además de intencional, la escritura es sintomática, reveladora y revelación, aun cuando oculta, y precisamente poque oculta. El escritor es el que dice lo que no se dice, el que dice lo no dicho, como el psicótico.

Los dos explicitan lo silenciado, lo subterráneo, lo que puede explotar. Pero en el psicótico, decir lo no dicho es parte de una realimentación. En el escritor, por el contrario, la palabra está pasando constantemente más allá de la metáfora y volviendo a su cruda resonancia original, como una lanzadera, para ser una meta-metáfora y quién sabe si no una dia-metáfora. Porque en el escritor, no así en el psicótico, la palabra es devenir.

El poder totalitario tiene que detener eso. Tiene que inmovilizar esa marea, fijarla, concretizarla, literalizarla para que nada cambie, para que el espejo de los gobernados devuelva una imagen estática, ilusión de eternidad, a la mirada de los gobernantes.

A veces se consigue, pero es un triunfo temporario. La censura exógena y la endógena que origina puede durar poco o mucho, pero se termina. Se termina porque el poder (totalitario) del que emana puede ser (a veces) duradero, pero es (siempre) frágil, pese a su aspecto férreo, debido a las exigencias de sus principios y de su naturaleza. Levantada la censura exógena, queda la otra, la endógena, más difícil de erradicar. Difícil, pero no imposible. Es en esta etapa en la que estamos ahora en la Argentina. Y se entrevé ya que el trabajo es largo, pero a escala, y que se va a terminar por vencer a las censuras.

¿Dije al principio que el lote que nos toca a las mujeres es doble invariablemente? Rectifico: en este caso es triple, porque a las dos censuras que las escritoras sufrimos junto con nuestros colegas masculinos, la de afuera y la de adentro como rebote, hay que sumar la otra.

¿Y cuál es esa otra? La de la ley. La que se levanta precisamente de un mundo que se pretende petrificado, un mundo antónimo de la marea de las palabras.

Junto con el adentro, a la mujer le fue decretado el silencio, y todavía hoy se oye del lado de Lacan que «la mujer no tiene palabra». Pero no hay patria en el silencio impuesto, y si bien acá el proceso es mucho más largo y no vemos sus extremos porque están encastrados en la historia, no hay duda de que hay que encontrar un hogar.

No es que de un tiempo a esta parte hayan comenzado a fluir unas gotas de literatura escrita por mujeres, y que esas gotas se hayan convertido en hilo, en arroyo, y estén próximas a ser catarata. Las cosas no son $\tan$ lineales. Siempre hubo escritoras. Seiscientos años antes de Cristo, 
como recuerda Virginia Woolf, un grupo de mujeres escribía poesía en una isla griega. Después volvió el silencio, y más tarde, en el año 1000, una mujer, Murasaki, escribe en el Japón, y vuelve a sobrevenir el silencio, y así hasta el siglo xvıII, cuando en la vida de la mujer de clase alta irrumpen la educación y el ocio.

Pero el mandato del silencio persiste, como persiste el mandato del adentro. En esa interioridad de serrallo sigue habiendo una obediencia que estimula al poder, y muy a menudo el abuso de poder se produce junto a un abuso de obediencia. La repetición de esa actitud avalada por un esquema al que se pretende petrificar mecaniza las respuestas y cancela toda reflexión: cuanto más mecánicamente se obedece, más profundamente se cree.

E1 paralelo con el proceso censor instaurado por un poder totalitario es evidente. Petrificar, matar la palabra, obtener el silencio es conseguir una ilusión de eternidad. Los roles, en uno y otro caso, han sido fijados de una vez para siempre, y si nada cambia, todo es eterno.

Entonces se acuña una expresión cómplice del silencio: miedo al cambio. $\mathrm{Y}$ eso nos hunde en el mundo del psicótico: las mujeres, se concluye, dicen lo que no se dice (el murmullo, el chisme, el rumor, el sentimiento). $Y$ lo que se quiere significar es: las mujeres dicen lo que los hombres no dicen.

¿Miedo a qué cambio? Estamos inmersas en el cambio. Nuestra fisiología, nuestra mirada, son cambio. La ley, contraria a la vida, es impotente para petrificar la palabra. La palabra es cambio. Y cuando una mujer escribe despojada de sumisión, la escritura que produce es siempre marginal, siempre implícita o explícitamente contestataria.

Hay otro mundo ahí que se incorpora al mundo masculino, gozando de lo prohibido porque está prohibido. Y en la escritura de la mujer se disipa entonces la amnesia que la protege contra la niña que la habita.

No es fácil vencer al silencio impuesto, pero es un imperativo.

Quizás en otras partes del mundo la situación sea distinta, pero en nuestra América Latina las escritoras, peleando contra las otras dos censuras que nos han afligido a todos y que aún afligen a muchos, vamos a terminar por derrotarlo.

Rosario, Argentina, marzo de 1984. 
